総説

\title{
腎疾患の進展阻止を目指した新しい治療戦略の開発
}

\author{
松本 紘一1) 福田 昇 ${ }^{1,2)}$ 上野 高浩1) 池田 和也 ${ }^{1)}$ \\ 奈倉千苗美 ${ }^{1)}$ 梶原麻実子1) 松本 史郎 ${ }^{1)}$ 丸山 高史 ${ }^{1)}$ \\ 羅 智靖3) 齋藤 烈(4) 松本 宜明 ${ }^{5}$ 杉山 弘 ${ }^{6}$ \\ ${ }^{1)}$ 日本大学医学部内科学系腎臓高血圧内分泌内科学分野 \\ ${ }^{2}$ 日本大学大学院総合科学研究科生命科学専攻 \\ ${ }^{3)}$ 日本大学医学部先端医学系分子細胞免疫・アレルギー学分野 \\ ${ }^{4)}$ 日本大学工学部バイオナノテク分野 \\ ${ }^{5}$ 日本大学薬学部臨床薬物動態学 \\ 6) 京都大学大学院理学研究科化学教室
}

\section{Development of Novel Therapeutic Strategies to Prevent the Development of Kidney Disease}

\author{
Koichi Matsumoto' ${ }^{1)}$, Noboru Fukuda ${ }^{1,2)}$, Takahiro Ueno ${ }^{1)}$, Kazuya Ikeda ${ }^{1)}$, \\ Chinami Nagura ${ }^{1)}$, Mamiko Kajiwara ${ }^{1)}$, Shiro Matsumoto ${ }^{1)}$ Takashi Maruyama $^{1)}$, \\ Chisei RA ${ }^{3)}$, Isao Saito ${ }^{4)}$, Yoshiaki Matsumoto ${ }^{5)}$ and Hiroshi SugiYama ${ }^{6)}$ \\ ${ }^{1)}$ Division of Nephrology, Hypertension and Endocrinology, Department of Medicine, Nihon University School of Medicine \\ ${ }^{2}$ Advanced Research Institute for the Sciences and Humanities, Nihon University Graduate School \\ ${ }^{3}$ Division of Molecular Cell Immunology and Allergology, Nihon University Graduate School of Medical Science \\ ${ }^{4)}$ Department of Materials Chemistry and Engineering, School of Engineering, Nihon University \\ ${ }^{5}$ Department of Clinical Pharmacokinetics, College of Pharmacy, Nihon University \\ ${ }^{6}$ Department of Chemistry, Graduate School of Science, Kyoto University
}

We provide a research update regarding novel therapeutic strategies to prevent the development of kidney disease and summarize the latest proceedings in this field. Chronic progressive kidney disease carries severe consequences and has limited treatment options. The purpose of this review is two-fold. The first aim is to provide a concise overview of the strategies of gene therapy, including pyrrole-imidazole polyamides (PI polyamides). PI polyamides are a new type of small compound that inhibit gene expression by binding to the minor groove of DNA. A PI polyamide that targets rat transforming growth factor- $\beta 1$ was designed as a gene-silencing agent for progressive kidney disease. In the future, control of gene expression by PI polyamides may ameliorate progressive kidney diseases that are not treatable with current medicine. Future therapeutic strategies aimed at alteration of the immune responses through manipulation of Fc $\gamma$ receptor interactions by the use of PI polyamides could be explored in the model of lupus nephritis. Thus Fc $\gamma$ receptor gene therapy provides an attractive strategy to develop an immunotherapy as a general treatment option. The second aim is to summarize the published data regarding the role of bone marrow stem cells in renal repair after acute and chronic kidney injury. Currently, much of our knowledge of renal protective effect of dedifferentiated fat (DFAT) cells is obtained through animal research. The results to date indicate that DFAT cells may provide a source for cell therapy for severe progressive kidney disease. Our goal is to understand the mechanism of renal protection by DFAT cells and to develop stratagems utilizing DFAT cells for the eventual treatment of patients with kidney disease. The importance of conservative regenerative medicine has recently been demonstrated. It has become apparent that angiotensin II receptor blockade (ARB) improves the proliferation and function of endothelial progenitor cells in hypertension, suggesting that $\mathrm{ARB}$ is useful to repair hypertensive renal injury. In this review, we will focus on the role of gene therapy and regenerative medicine as therapeutic modalities in kidney disease.

Key words: kidney, chronic kidney disease, gene therapy, regenerative medicine 腎藏, 慢性腎藏病, 遺伝子治療, 再生医療

(J. Nihon Univ. Med. Ass., 2009; 68 (6): 315-321)

はじめに

慢性腎臓病 (CKD) 概念の医家や国民への啓蒙活動が広 がり，弚の重要性が益々認識されてきた。CKD は末期
腎不全への予備軍としての重要性のみならず, 心血管系 疾患の重大な危険因子であることが, 多くの疫学調査に より判明してきた . 我が国の透析患者数は約 30 万人に到 達する勢いであり，CKD の進行阻止を目指す根本的な

受付: 2009 年 10 月 1 日, 受理: 2009 年 11 月 4 日 
治療戦略の開発が急務である. 本稿ではこれに対処すべ く，主に遺伝子治療と再生医療の進歩の軌跡を論述す る。

21 世紀の分子生物学の発展は, 現在の医療では根治が 困難である難治性進行性腎疾患に対して遺伝子治療の䨿 を開きつつある . 最近 transforming growth factor (TGF)$\beta 1$ 遺伝子発現を抑制する新規遺伝子制御薬 pyrrole-imidazole polyamide (PI ポリアミド) の効果が高血圧性腎障 害モデルで証明された . 同時に , ループス腎炎治療薬と しての Fc 受容体 $\gamma$ 鎖に対するPI ポリアミドの開発も進 行している.これらの研究は進行性腎障害に対する経口 可能な遺伝子治療薬の開発に繋がることか期待される. 更に TGF- $\beta 1$ に対するキメラ型リボザイムによる実験的 被囊性腹膜硬化症 (EPS) の遺伝子治療の開発も推進され ている。

再生医療は CKD の次世代の治療法として期待され， 兴の研究が日進月歩の進展をみせている.腎臓再生の研 究としては, 骨髄細胞からの系球体メサンギウム細胞, 系球体内皮細胞の分化誘導が試みられてきた。また細胞 源として脱分化成熟脂肪細胞 (DFAT) からの腎尿細管上 皮細胞への分化誘導も行われている. 再生医療の細胞源 としては胚性幹細胞や体性幹細胞を利用するのが主流で あるが，倫理上の問題や細胞採取に伴う侵襲性が大き い. 我々はこれらの難題を解決すべく，ドナー細胞とし て大量に調達が可能な DFAT に注目して, 腎臓再生や修 復における有用性を実験動物で解析している。また DFATから腎尿細管上皮細胞への分化誘導を試みている

更に著明な高血圧症性腎硬化症を示す脳卒中易発生高 血圧自然発症ラット (SHR-SP) の腎藏において, アンジ オテンシン II 受容体拮抗薬 (ARB) 投与後の腎臓幹細胞 の増加による腎障害の進展抑制の研究も進展している. 幹細胞寿命は酸化ストレスおよび酸化シグナルによって 規定されている，抗酸化作用を持ち幹細胞寿命を延長 し，腎障害の進展を抑制する薬剤か想定され，保存的再 生医療の開発を視野に入れた研究が展開している.

本総説では最近の研究結果の進展を中心に論述すると ともに, 新しい腎疾患治療戦略開発の進歩に一歩でも迫 りたい。

\section{I. 遺伝子治療}

1. 腎疾患における遺伝子治療の可能性

21 世紀を迎え腎疾患の遺伝子治療が末来医療の一環と して重要な位置を占める可能性がある. 従来は Alport 症 候群の樣に単一遺伝子異常による腎疾患が关の候補とし て挙げられてきた ${ }^{11}$. ここ数年来, 先天性ネフローゼ症 候群の原因遺伝子の解析が進み, 遺伝子治療がこの疾患 の治療法に寄与する可能性がある .これらの疾患の腎機 能の正常化を目指す遺伝子治療は, 現在有効な゙治療法が 無い事を懸案すれば大きな福音をもたらす事になろう .
遺伝子治療は, 遺伝子欠損または遺伝子異常に起因す る疾患に遺伝子光のものを補填する方法と，遺伝子の過 剩発現により惹起される疾患・病態の修復のために遺伝 子発現を抑制する方法に大別される。慢性腎疾患 (CKD) においても IgA 腎症の原因遺伝子の検索・解析が進めら れている2). 然しながら系球体腎炎の遺伝子治療は未だ 実験室レベルの段階で研究が進行しているのか現状であ る.今後は, 日常診療で遭遇する頻度が高い腎疾患て遺 伝子発現の変異やシグナル伝達異常の解析を行い, 病因 となる責任標的候補を探索・同定する必要がある. これ 等の研究結果を踏まえ如何に有効にゲノム創薬に結び付 けることが出来るかがより重要となってきた .

\section{2. 腎疾患治療における遺伝子治療の現状}

IgA 腎症をはじめとする慢性腎炎においては系球体障 害よりも寧ろ尿細管間質障害の程度か腎機能の保持に重 要である . 尿細管間質線維化の進行を抑制・遅延させる ことか腎疾患患者の予後の改善に繋がる.これに鑑み， 例えば腎組織線維化への関与が示唆されている transforming growth factor (TGF)- $\beta$ の産生細胞における兴の 発現抑制の手法として，これまでに，アンチセンスオリ ゴ, デコイ核酸医薬，リボザイムや small interfering RNA (siRNA)などの核酸医薬が開発され腎疾患線維化の 抑制手段として研究段階で注目を集めてきた ${ }^{3)}$. 然しな がら, これらの核酸医薬は生体内において主に核酸分解 酵素によって分解され易く, 生体へのデリバリーが困難 であることが最大の欠点である.これらの理由により， 充分な線維化抑制の効果か得られないのか現状である. これらの核酸医薬を腎藏に作用させる時には, 高い発現 効率と長期間の安定性が要求される.これらの核酸医薬 は長期作用可能な医薬品という観点からは充分とは言い 難い，慢性に進行する腎疾患の遺伝子治療においては， 長期間有効な核酸医薬の更なる開発が望まれる.

被囊性腹膜硬化症 (EPS) は腹膜透析患者に発症する， 稀ではあるか㴛死的な合併症である . 丸山ら ${ }^{4)}$ は TGF- $\beta 1$ mRNA に対する DNA-RNA キメラ型リボザイムによる EPS の遺伝子治療の開発に着手している .この実験結果 は, 腹膜の線維化，硬化が有意に抑制されることを証明 し，EPS に対する新規の遺伝子治療の方向性を示した。

3. 新規遺伝子治療薬 pyrrole-imidazole polyamide の 開発

pyrrole-imidazole polyamide (PI ポリアミド) は抗生剂 から合成された新規の遺伝子治療薬である ${ }^{5)}$. 光の特徵 は DNA を塩基配列特異的に認識する有機化合物であり， 核酸分解酵素で分解されず生体内で安定性がある.更に ベクター無しに組織に取り込まれ，核に強力にデリバ リーされる . TGF- $\beta$ に対する PI ポリアミドの in vivo 実 験においても，これを裏付ける結果が得られており，光 
の作用は既存の核酸医薬に比して強力であることか確認 されている6).

PI ポリアミドは如何なる分子に対しても設計が可能で あり，従来の核酸医薬にはなかった利点が多々みられ る .このようにPI ポリアミドはこれまでの核酸医薬の 易分解性, ベクターの必要性などの欠点を克服した新規 の遺伝子治療薬であり, 経口可能な遺伝子治療薬として も独創的な位置を占めている゙. 固相法によるPI ポリア ミドの合成法は日本大学と京都大学の共同研究て確立し ており，既に特許化されている (特願 2005-336811)．

ゲノム創薬が日進月歩で発展しており，将来の CKD 治療戦略へのPI ポリアミドの導入が期待される . siRNA は遺伝子抑制効果の特異性および炎の強度において優れ ているが, 生理的に発現している標的遺伝子まで抑制し てしまい, 副作用の出現か縣念されている7). これに対 し，PI ポリアミドは遺伝子配列特異的にDNA に結合す るため, 副作用の発生頻度を抑制出来る長所がある．PI ポリアミドは疾病で増加した遺伝子活性のみを抑制する ため, 生理的に発現している遺伝子は抑制しないことが 実験的に立証されている . 病因遺伝子のみを抑制するた め, 副作用の面において安全であり, 将来の臨床応用人 の可能性を秘めている .

松田らは実験的進行性腎障害の遺伝子治療薬として TGF- $\beta 1$ プロモーターに対する PI ポリアミドを分子設計 して，弚の効果を詳細に検討した ${ }^{8)}$. PI ポリアミドは血 管平滑筋細胞の核に投与 2 時間後より集積し, 弚の存在 は約 96 時間持続することが確認された . FITC をラベル した PI ポリアミドをラットに経静脈または経口で投与 すると，血管内皮，腎系球体および尿細管に取り込まれ た . また液体高速クロマトグラフィーにより尿中への排 泄も確認できた . PI ポリアミドは血管平滑筋細胞や腎メ サンギウム細胞の核に存在する二本鎖 DNA に結合する ことにより，TGF- $\beta 1$ の転写活性を抑制することが立証 された ${ }^{8)}$. PI ポリアミドは既存の核酸医薬と異なり，核 酸構造を持たない低分子化学合成物質であるため生体に おいてもドラッグデリバリーシステムを必要としない利 点がある. 単独投与によってもメサンギウム細胞の核, 尿細管細胞の核に効率良く取り込まれることか証明され ている8)

松田ら( ${ }^{8)}$ TGF- $\beta 1$ を標的としたPI ポリアミドの投与 により，進行性腎障害モデルにおける系球体硬化進展の 有意な抑制効果を認めた . 高血圧性腎障害のモデルであ る Dahl 食塩感受性高血圧ラットに TGF- $\beta 1$ に対する PI ポリアミドを 2 週間投与したところ, 血圧や体重には影 響せず，尿蛋白や微量アルブミンの排泄を有意に抑制し た . 更に，引き続き 4 週間投与したところ，病理組織学 的に腎系球体硬化の進展は有意に抑制された．また投与 期間内では明らかな副作用の発現はみられず, 安全性の 上からも評価できた .これらの結果から PI ポリアミド
は動物実験のレベルにおいては進行性腎障害の遺伝子治 療薬としての有効性と安全性か碓認された . 実際の臨床 の場では, より長期作用可能な医薬品としての遺伝子治 療薬が必要になり, 有効性と安全性の両面から更なる研 究の蓄積が必要になる。

系球体腎炎は Fc 受容体 $(\mathrm{R}) \gamma$ 鎖ノックアウトマウス では起きないことから，自己免疫性系球体腎炎の引き金 はFcR $\gamma$ 鎖が重要であると考えられている9). 我々は進 行性腎障害を抑制できる可能性の高い Fc $\gamma$ R の F c $\gamma$ RII，III と Fc $\varepsilon$ RI の共通ドメインである $\gamma$ 鎖を抑制す ることを目的に，難治性自己免疫腎炎であるループス腎 炎に対する遺伝子治療薬として PI ポリアミドの分子設 計と創薬開発を試みている.開発したPI ポリアミドは マウスFcer1g 遺伝子発現を抑制し，さらに細胞表面での FcR 発現も減少させることが示され，本薬剤はFcR $\gamma$ 鎖 が大きな役割を担うと考えられるループス腎炎などの難 治性自己免疫疾患の遺伝子治療薬として期待出来る. 全 身性エリテマトーデス (SLE) は全身性疾患として, ステ ロイド治療が実施されているが，長期間の大量投与によ る骨粗鬆症などの副作用の出現が大きな問題である . ループス腎炎の病因・病態に密着した画期的な゙治療戦略 の開発が望まれる. 弚の戦略の一つとして FcR $\gamma$ 鎖を ターゲットにする遺伝子治療か開発されれば，SLEにお けるループス腎炎および血管炎を特異的に制御出来る治 療戦略として将来有力になる可能性がある. 将来の核酸 医薬を用いたループス腎炎の遺伝子治療の実用性も視野 に入れ，PI ポリアミドの薬物動態や安全性などの基礎的 な研究の進展を期待したい . 遺伝子をコントロールする 核酸医薬の開発戦略力酻成され, 実際のSLE 治療の医療 現場に臨場感を持って登場する日が俟たれる．

将来の PI ポリアミドの臨床応用には解決すべき多く の障壁が存在する . 例えば，PI ポリアミドの特異性，薬 物動態, 基礎物性, 細胞透過性, 藏器への取り込みの更 なる検討が必須である. 安全性, 反復投与毒性試験，致 死量，最適投与量，投与間隔などの詳細な検討も求めら れている、進行性腎障害に対するPI ポリアミドによる 遺伝子治療の研究が更に加速され，CKD の画期的な根 本治療開発の礎になること期待したい .

\section{II. 腎臓再生と腎臓障害の修復}

\section{1. 骨髄細胞}

CKD の進行には障害進展因子と修復因子のバランス か密接に関与している.近年, 再生医学の視点から腎障 害の進行を制御する研究が注目されている ${ }^{10)}$. 近年, 骨 䯣細胞 (造血幹細胞, 間葉系幹細胞) を用いる細胞治療が 検討され，再生医療進展の大きな要因となった . 骨骨造造 血幹細胞や間葉系幹細胞の可塑性が明らかになり，腎蔵 構成細胞のなかには果して骨髄細胞から分化する細胞が あるのであろうか? 骨髄は生体の恒常性維持の為の多能 
性幹細胞の源泉としての役割があると考えられている .

$\operatorname{IgA}$ 腎症の経過中に急性骨髄性白血病を併発した症例 に，同種骨髄移植を施行したところ，系球体の $\operatorname{IgA}$ と補 体 C3 の沈着が消失したことが報告され，骨骨道細胞が腎 障害の修復機転に関与している可能性が示唆された ${ }^{11)}$. 系球体内皮細胞障害は腎疾患の病因で重要な役割を果す と同時に，腎障害の進行において中心的な役割を演じて いる．抗胸腺細胞抗体腎炎は一過性のメサンギウム細胞 障害と二次的な系球体内皮細胞障害のモデルである .こ の実験腎炎において骨骨道由来の細胞が系球体内皮細胞と メサンギウム細胞の turn over に関与しており，微小血 管の修復に関与していることが報告されている ${ }^{12)}$. 急性 腎疾患モデルの回復期に腎臓構成細胞が再生するが, 关 のメカニズムは明らかではない，井下ら ${ }^{13)}$ は系球体修復 機序における骨髄由来細胞の関与について検討した . B6 マウスを全身照射し, green fluorescence protein (GFP) マ ウスの骨髄を移植した後, 腎障害モデルとしてハブ毒で メサンギウム基質を融解する腎炎を作成した，腎蔵の修 復を組織学的に評価し, 再生組織が GFP 陽性細胞であ るかを解析した．弚の結果，この実験的腎炎の系球体修 復に骨髄細胞か関与している可能性が示唆された ${ }^{13)}$. 更 に腎不全動物モデルであるテナスシンノックアウトマウ スに自家骨髄細胞を投与した結果, 骨髄細胞が腎藏入動 員され障害部位を修復することが証明された ${ }^{13)}$.

近年, 骨髄幹細胞が尿細管細胞へ分化する可能性が報 告された . Kale らは ${ }^{14)}$, 急性尿細管壊死モデルマウスの 腎尿細管の修復の病態において, 骨髄幹細胞か障害部位 へ遊走して尿細管上皮細胞入分化し，壊死細胞の修復構 築に寄与すると報告した .一方，Duffield ら ${ }^{15)}$ は骨髄由 来の細胞は虚血性腎障害後の尿細管上皮細胞の修復には 寄与しないとの見解を示した . Lin らは ${ }^{16)}$ 虚血再還流の 腎障害モデルでは 89\%の増殖性尿細管上皮細胞は宿主細 胞からの起源であり，11\%のみがドナー骨髄細胞に由来 していると述べている．然しながらこの骨髄細胞を移植 されたマウスでは腎機能の改善はみられなかった .これ らの結果より腎臓修復の主な細胞源は腎固有の細胞であ り, 骨髄細胞単独の移植では腎機能の回復や腎構造の修 復には寄与しないと結論した .

骨髄細胞が腎臓構成細胞入直接分化する可能性より も，骨髄細胞から分泌される液性因子が paracrine, endocrine に作用し抗アポトーシス作用，血管新生作用，細胞 増殖作用を助長し，腎障害の修復に関与する可能性が示 唆されている．骨髄細胞が何処まで腎藏の再生や修復に 関与するのかは今後の研究の進展に俟ちたい .

\section{2. 脱分化脂肪細胞}

腎藏, 特に尿細管再生の研究が推進されるにつれ, 光 れに呼応して現在まで再生医療用のドナー細胞の開発が 鋭意進められてきた . 脱分化成熟脂肪細胞 (DFAT) は少
量の成熟脂肪細胞からコラーゲナーゼ処理とフィルト レーション後の天井培養によって単一な細胞群として採 取することが出来る ${ }^{17)}$. DFAT は多分化能を有するのみ ならず，長期間継代培養しても形質転換することなく， 均一な増殖および分化能を保持し容易に増殖させること が出来る、従って従来型の幹細胞による再生医療から脱 却した簡便で安全性の高い再生医療の実現性がある17)。 また DFAT は大量培養が可能であるため，凍結によるバ ンキングが出来, 将来的には急性腎障害や進行性腎障害 の病態に対しても移植の可能性が秘められている.

DFAT を種々の分化誘導条件下で培養すると，血管内 皮細胞, 血管平滑筋細胞, 心筋細胞, 腎尿細管細胞など へ分化転換することが証明されている17). 年齢を問わず 調整が可能なことから，全身状態不良の患者や高齢者な ど，自己幹細胞移植が困難である患者に対する新規の再 生ドナ一細胞として有力な候補としての位置を獲得する 可能性が示唆されている.

山元ら ${ }^{18)}$ は間葉系細胞である DFAT に Wnt-4 遺伝子 導入後, bone morphogenic protein-7 で刺激して上皮細胞 への分化転換 (mesenchymal-epithelial transition: MET) の 誘導を試みた．光の結果，上皮細胞のマーカーである E-cadherin や尿細管のマーカーである aquaporin 2 mRNA の発現が確認された .さらに hepatocyte growth factor (HGF) の存在下でマウス DFAT と尿細管上皮細胞株 (MDCK 細胞) をコラーゲンゲル内で共培養すると， MDCK 細胞の管空形成と管空内への DFAT 細胞の取り 込み現象がみられた .この事実は DFAT 細胞から尿細管 上細胞への分化転換の可能性を示唆している ${ }^{18)}$.

DFAT による腎臓再生治療の開発のために腎障害モデ ルを使用した解析が推進されている . Nurら ${ }^{19)}$ はテナス シンノックアウトマウスにハブ毒を投与して慢性腎不全 モデルを作成した .このモデルでは進行性の系球体硬化 が惹起され腎機能障害を併発する .この実験動物に GFP マウスから調製した DFAT を移殖すると，腎藏の系球体 および尿細管に取り込まれることが蛍光抗体法によって 確認された．更に光の移植により腎障害の進行は有意に 抑制され, 系球体硬化係数の低下とともに, 血清尿素窒 素の低下がみられた ${ }^{19)}$ (Fig. 1)．この事実は DFAT 移植 が本モデルの病態生理に深く関与しており，腎障害の進 展を阻止したことが示唆された . 細胞移植による腎障害 進展抑制は移植した細胞の分化のみならず, DFAT から 大量のサイトカインや HGF などの成長因子が産生さ れ, 乥れらか障害腎組織の自己再生を助長した可能性も 示唆された。

将来の腎藏病領域における実用化を踏まえ，実際の投 与効果, 投与方法, 安全性などの更なる基礎的な研究の 積み重ねが必要である. 成熟脂肪細胞に由来する DFAT は従来の幹細胞とは異なる新規の腎蔵再生のドナー細胞 として有望と考えられる. 腎臓产のものを再生すること 
a TC-KO

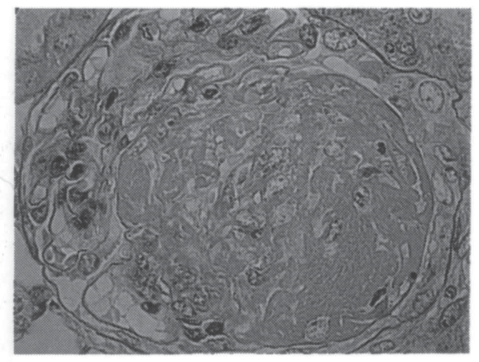

TC-KO + DFAT cells

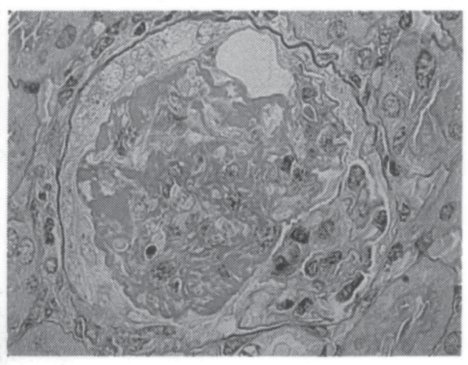

PAS stain b

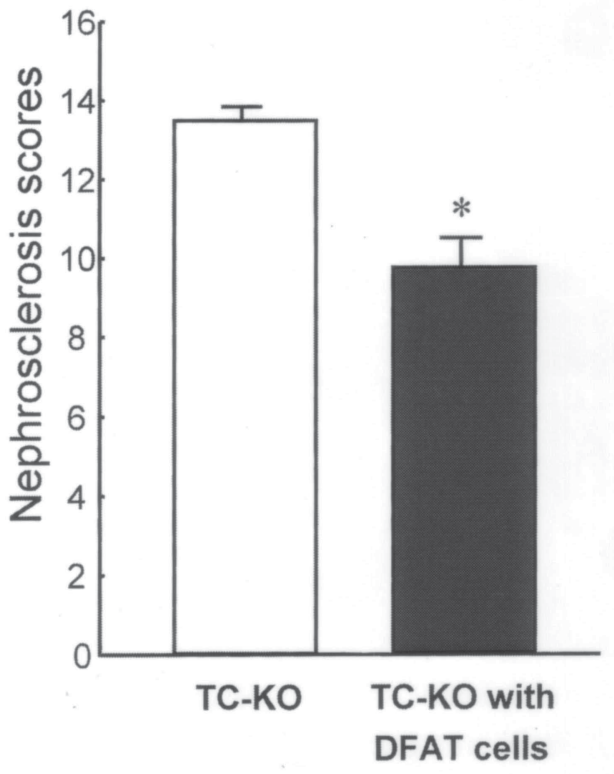

Glomerular injury scores in TC-KO mice

Fig. 1 A: Effect of implantation of dedifferentiated fat (DFAT) cells ameliorates habu snake venom (HSV)-induced chronic renal dysfunction in tenascin-c-knockout (TC-KO) mice. HSV injection induced mesangial proliferation and glomerulosclerosis, which were significantly improved by implantation of DFAT cells. B: The glomerular injury score was significantly $(* \mathrm{p}<0.05)$ lower in TC-KO mice with implanted DFAT cells than in those without (文献 19 より引用).

は現時点では困難であるが, 少なくとも尿細管の機能回 復に繋がる臨床応用へ向けた新たな細胞移植の治療法の 開発か期待される . 細胞移植で $10 \%$ 程度の部分的な腎機 能回復が可能となれば产の臨床的意義は極めて大きい . 腎藏再生の研究は着実な進歩がみられているといえる。

\section{3. 保存的再生医療}

我々は腎疾患の成因として腎臓体性幹細胞の機能低下 や寿命の短縮か関与しているとの仮説を立てている . 幹 細胞寿命は酸化ストレスおよび酸化シグナルによって規 定されている ${ }^{20)}$. 抗酸化作用を持ち幹細胞寿命を延長 し，腎障害を修復する薬剤や食品の存在が想定され，血 管内皮前駆細胞 (EPC) や腎藏体性幹細胞への作用の解析 が重要になる。このように薬斉による腎藏再生・修復を 体系付ける事が出来れば，保存的再生医療の開発に繋が る。

今後の方向性として固有の腎蔵再生能力を高める治療 法の重要性が高まると予想される.生体の多くの藏器で 体性幹細胞力確認されている.これらは組織幹細胞とも 呼ばれ，多分化能を持ち，組織を形成している種々の機 能細胞の定常状態を保持している．最近では，腎蔵にお いても組織幹細胞が存在する事が報告されている21 23) . 腎臓再生への近道として内在する腎蔵幹細胞 (前駆細
胞) を活性化する方法が考えられる，腎蔵幹細胞を特異 的に活性化する因子の検索が効率のよい再生療法の開発 に繋がる可能性がある. 特異的かつ選択的な腎蔵再生促 進因子の探索と治療薬の有効性の確認が光の具体化に寄 与する，腎臓幹細胞機能を高める方法が将来進行性腎障 害の再生医療として最も有効になる可能性がある . 幹細 胞は多分化能と自己複製能を併せ持つ細胞であり, 幹細 胞の維持と分化には周囲に存在する微小環境 (niche) が 重要な役割を果している. 腎幹細胞は, 周囲の niche と の相互作用によって乥の未分化性を維持し, 非対称分裂 によって娘細胞と分化細胞を生み出している．腎不全状 態において腎葴局所で腎幹細胞に適した niche が整って いる可能性は極めて低い . 如何にしてこの腎幹細胞に適 合する新たな微小環境造りが出来るかが重要である．腎 藏再生には源になる細胞, 足場, 再生誘導因子の 3 要素 が重要になる.腎蔵再生には腎組織に分化可能な新たな 腎臓幹細胞または細胞群を探査・同定することが必要に なる．保存的腎蔵再生医療は兴のような問題を解決し て，はじめて新たな治療法として飛躍することが出来 る. niche に付着している幹細胞は酸化ストレスにより 機能が減弱し，細胞周期が短縮することか報告されてい $ろ^{24)}$. 従って, 幹細胞機能を改善する制御因子の同定も 重要である. 現在の研究成果は醸成されつつあり，保存 
的腎臓再生療法がより現実的なものに発展することが期 待される。

臨床応用の視点からすると光の主役として, 樣々な細 胞への分化能力を有する多能性体性幹細胞が注目され る. Bromodeoxyuridine (BrdU) は DNA 合成期にある 細胞にとり込まれるため, 増殖スピードの速い細胞は BrdU が希釈される . Label retaining cell (LRC) は細胞分 裂の非常に遅い細胞 (slow-cycling cell) であり，BrdU を 保持していることから LRC と命名された ${ }^{23)}$.この BrdU 陽性細胞は最終的には成熟した尿細管上皮細胞への分化 能を有しており，腎臓幹細胞の役割を担うことか報告さ れている．LRC の多くは近位尿細管に存在しており， ラット虚血再還流障害の急性腎不全モデルの回復過程に おける尿細管再生に中心的な役割を演じていることが示 唆されている25).

Yao らは ${ }^{26)}$, 保存的再生医療の開発の礎として, アン ジオテンシン II 受容体拮抗薬 (ARB) の EPC への作用を 酸化ストレスモデルである脳卒中易発生高血圧自然発症 ラット (SHR-SP) を用いて詳細に解析した。关の結果， ARB には酸化ストレスの病態において，低下した EPC 機能を賦活させる作用があることが判明した .この細胞 生物学的研究から ARB は高血圧性腎障害の修復に密接 に寄与していることが示唆された . 間葉系幹細胞とレ二 ン・アンジオテンシン系 (RAS) の局所でのクロストーク も報告されており27)，ARB の新たな展開か期待される . ARB は腎臓体性幹細胞や前駆細胞に作用して腎臓の保護 作用を促進することが示唆される．RAS の抑制が腎障害 の進行を抑制するのみならず，腎臓再生にも寄与する可 能性が示唆される.RAS 阻害薬は腎障害抑制薬としての 作用のほか, 腎臓再生薬としての期待が持たれる.今後 の保存的腎臓再生医療開発の更なるブレイクスルーか期 待される。

RAS の機能え進は腎藏障害の進行因子として知られて いる . アンジオテンシン II (AG II) は TGF- $\beta 1$ や I 型コ ラーゲンの発現を穴進さる腎藏間質線維化の促進因子で あり，この過程に活性酸素が深く関与している.更に AGII は NADP (ニコチンアミドアデニンジヌクレオチド リン酸) オキシダーゼを介し活性酸素の産生を増加さ せ, 光の結果 endothelin 1 の発現を亢進させる . 同時に 交感神経系の活性を上昇させたり，腎藏局所の血流を低 下させる .酸化ストレスは活性酸素産生系と光の消去系 のバランスが崩れ，活性酸素が過剩に産生された状態で ある.酸化ストレスは血管内皮機能障害を惹起し，谷の 結果高血圧性腎障害や糖尿病性腎症などの血管疾患の病 態に関与することが示唆されている ${ }^{28)}$. Yao ら ${ }^{26)}$ (酸化 ストレスモデルである SHR-SP を用いて，ARB は白血 球や腎皮質血管壁細胞膜，細胞質および血管平滑筋の酸 化ストレスを改善し，EPCの機能を修復する事を証明し た . ARB には新たに抗酸化作用か認められ，活性酸素の
消去も目的とした治療薬としても使用される可能性があ る.CKD の新たな゙治療開発には抗酸化作用や幹細胞寿 命を延長する薬剂や食品の検索・解析がより重要になる であろう。

細胞移植による再生医学・医療のみならず腎藏幹細胞 寿命を延長し, 藏器障害を改善する保存的再生医療の開 発が重要であることを強調したい，再生医学研究の潮流 は, 基礎的研究段階から, より実用的な臨床応用研究段 階へと変貌しつつある. 腎臓再生医学の分野において も, 分子生物学や細胞生物学研究の進展と歩を一にし て, 安全かつ効果的な再生医療の開発に繋がる研究が着 実に進行している。

\section{おわりに}

ヒトの腎疾患に対する分子医療の確立には解決しなけ ればならない多くの難題が存在する. 今後更なる遺伝子 制御と再生医学の研究が進展し, 難治性腎疾患の治療に 福音をもたらす事が期待される .

謝 辞 本研究は平成 21 年度日本大学学術研究助成金 (総合研究) の援助を受けた . 本論文作成に御協力戴いた 日本大学医学部腎藏高血圧内分泌内科学分野秘書, 関 恵美氏に深謝する .

\section{文献}

1) Tryggvason K, Heikkilä P, Pettersson E, et al. Can Alport syndrome be treated by gene therapy? Kidney Int 1997; 51: 14931499.

2) Hsu SI, Ramirez SB, Winn MP, et al. Evidence for genetic factors in the development and progression of IgA nephropathy. Kidney Int 2000; 57: 1818-1835.

3) Tahira Y, Fukuda N, Endo M, et al. Chimeric DNA-RNA hammerhead ribozyme targeting transforming growth factor- $\beta 1$ mRNA ameliorates renal injury in hypertensive rats. J Hypertens 2007; 25: 671-678.

4) 丸山範晃, 福田 昇, 岡田一義, 松本紘一. TGF- $\beta 1$ mRNA に対する DNA-RNA キメラ型リボザイムによる被 囊性腹膜硬化症の遺伝子治療の開発. 日本腎蔵学会誌, 2007; 49: 113-120.

5) Harki DA, Satyamurthy N, Stout DB, et al. In vivo imaging of pyrrole-imidazole polyamides with positron emission tomography. Proc Natl Acad Sci USA 2008; 105: 13039-13044.

6) Lai Y-M, Fukuda N, Ueno T, et al. Synthetic pyrrole-imidazole polyamide inhibits human transforming growth factor- $\beta 1$ gene expression. J Pharmacol Exp Ther 2005; 315: 571-575.

7) McManus MT, Sharp PA. Gene silencing in mammals by small interfering RNAs. Nat Rev Gent 2002; 3: 737-742.

8) Matsuda H, Fukuda N, Ueno T, et al. Development of gene silencing pyrrole-imidazole polyamide targeting the TGF- $\beta 1$ promoter for treatment of progressive renal diseases. J Am Soc Nephrol 2006; 17: 422-432.

9) Suzuki Y, Shirato I, Okumura K, et al. Distinct contribution of $\mathrm{Fc}$ receptors and angiotensin II-dependent pathways in antiGBM glomerulonephritis. Kidney Int 1998; 54: 1166-1174.

10) Little MH. Regrow or repair: potential regenerative therapies for the kidney. J Am Soc Nephrol 2006; 17: 2390-2410. 
11) Iwata $Y$, Wada T, Uchiyama A, et al. Remission of IgA nephropathy after allogeneic peripheral blood stem cell transplantation followed by immunosuppression for acute lymphocytic leukemia. Intern Med 2006; 45: 1291-1295.

12) Rookmaaker MB, Smits AM, Tolboom H, et al. Bone-marrowderived cells contribute to glomerular endothelial repair in experimental glomerulonephritis. Am J Pathol 2003; 163: 553562. Hill JM et al. N Engl J Med 2003; 348: 593-600.

13) Inoshita A, Okada K, Fukuda N, et al. Bone marrow cells may repair mesangiolysis in Habu snake venom-induced glomerulonephritis mice. Nihon Univ J Med 2009; in press.

14) Kale S, Karihaloo A, Clark PR, et al. Bone marrow stem cells contribute to repair of the ischemically injured renal tuble. $J$ Clin Invest 2003; 112: 42-49.

15) Duffield JS, Park KM, Hsiao LL, et al. Restoration of tubular epithelial cells during repair of the postischemic kidney occurs independently of bone marrow-derived stem cells. J Clin Invest 2005; 115: 1743-1755.

16) Lin F, Cordes K, Li L, et al. Hematopoietic stem cells contribute to the regeneration of renal tubles after renal ischemia-perfusion injury in mice. J Am Soc Nephrol 2003; 14: 1188-1199.

17) Matsumoto T, Kano K, Kondo D, et al. Mature adipocyte-derived dedifferentiated fat cells exhibit multilineage potential. $J$ Cell Physiol 2008; 215: 210-222.

18）山元智衣, 松本太郎, 加野浩一郎, 他. 脂肪細胞から尿 細管上皮細胞への transdifferentiation. 腎臓，2006; 28: 185-189.

19) Nur R, Fukuda N, Matsumoto T, et al. Implantation of dedifferentiated fat cells ameliorates habu snake venom-induced chronic renal dysfunction in tenascin-c-deficient mice. Nephron Exp Nephrol 2008; 110: e91-e98.
20) Chan EC, Jiang F, Peshavariya HM, et al. Regulation of cell proliferation by NADPH oxidase-mediated signaling: potential roles in tissue repair, regenerative medicine and tissue engineering. Pharmacol Ther 2009; 122: 97-108.

21) Cantley LG. Adult stem cells in the repair of the injured renal tuble. Nat Clin Pract Nephrol 2005; 1: 22-32.

22) Challen GA, Bertoncello I, Deane JA, et al. Kidney side population reveals multilineage potential and renal functional capacity but also cellular heterogeneity. J Am Soc Nephrol 2006; 17: 1896-1912.

23) Maeshima A. Label-retaining cells in the kidney: origin of regenerating cells after renal ischemia. Clin Exp Nephrol 2007; 11: 269-274.

24) Hosokawa K, Arai F, Yoshihara H, et al. Function of oxidative stress in the regulation of hematopoietic stem cell-niche interaction. Biochem Biophys Res Commun 2007; 23: 578-583.

25) Maeshima A, Yamashita S, Nojima Y. Identification of renal progenitor-like tubular cells that participate in the progression processes of the kidney. J Am Soc Nephrol 2003; 14: 31383146.

26) Yao E-H, Fukuda N, Matsumoto T, et al. Losartan improves the impaired function of endothelial progenitor cells in hypertension via an antioxidant effect. Hypertens Res 2007; 30: 11191128.

27) Sahai E, Olson MF, Marshall CJ. Cross-talk between Ras and Rho signaling pathways in transformation favours proliferation and increased motility. EMBO J 2001; 20: 755-766.

28) Forbes JM, Coughlan MT, Cooper ME. Oxidative stress as a major culprit in kidney disease in diabetes. Diabetes 2008; 57 : 1446-1454. 